18. Bishop, C. M. Neural Networks for Pattern Recognition/ C. M. Bishop // Oxford : Clarendon Press, 1995. - 482 p.

19. Vapnik, $V . N$. The Nature of Statistical Learning Theory / V. N. Vapnik - N. Y. : Springer, 1995. - 188 p.

20. Vapnik, V. N. Statistical Learning Theory: Adaptive and Learning Systems / V. N. Vapnik - N. Y. : John Wiley \& Sons, 1998. $-736 \mathrm{p}$.

21. Least Squares Support Vector Machines / [Suykens J.A.K., Gestel T.V., Brabanter J.D. and other]. - Singapore : World Scientific, 2002. $-294 \mathrm{p}$

22. Lin, Ch.-F. Fuzzy Support Vector Machines / Ch.-F. Lin, Sh.-D. Wang. - IEEE Trans. on Neural Networks. - 2002. T. 13., № 2. - P. 646-471.

23. Tsujinishi, D. Fuzzy Least Squares Support Vector Machines for multiclass problems / D. Tsujinishi, S. Abe. - Neural Networks, 2003. - Vol. 16. - P. 785-792.

24. Hansen, L. K. Neural networks ensembles / L. K. Hansen, P. Salamon // IEEE Trans. on Pattern Analysis and Machine Intelligence. - 1990. - Vol. 12. - P. 993-1000.

25. Sharkey, A.J.C. On combining artificial neural nets / A. J. C. Sharkey // Connect. Sci. - 1996. - Vol. 8. - P. 299-313.

26. Hashem, S. Optimal linear combination of neural networks / S. Hashem // Neural Networks.- 1997. - Vol. 10. - P. 599-614.

27. Naftaly, U. Optimal ensemble averaging of neural networks / U. Naftaly, N. Intrator, D. Horn // Network : Comput. Neural Syst. - 1997. - Vol. 8. - P. 283-296.

28. Бодянський $Є$. В. Адаптивне виявлення розладнань в об'єктах керування за допомогою штучних нейронних мереж / Є. В. Бодянський, О. І. Михальов , I. П. Плісс. - Дніпропетровськ : Системні технології, 2000. - $140 \mathrm{c}$.

29. Поляк, Б. T. Введение в оптимизацию / Б. Т. Поляк. - М. : Мир, 1984. - 541 с.
30. Бодянский, E. В. Адаптивное обобщенное прогнозирование многомерных случайных последовательностей / Е. В. Бодянский , И. П. Плисс, Т. В. Соловьева. - Доклады АН УССР. - 1989. - А. - № 9. - С. 73-75.

Стаття надійшла до редакції 20.02.2012.

Дейнеко А. А., Плисс И. П., Бодянский Е. В.

КОМБИНИРОВАННОЕ ОБУЧЕНИЕ ЭВОЛЮЦИОННОЙ НЕЙРО-ФАЗЗИ СИСТЕМЫ

Предложена архитектура эволюционной нейро-фаззи системы, которая не склонна к проклятию размерности, способна обрабатывать информацию в режиме реального времени, адаптируя при этом свои параметры и структуру к условиям задачи. В качестве активационных функций были использованы ядерные функции активации.

Ключевые слова: эволюционная нейро-фаззи система, нормализованная радиально-базисная нейронная сеть, обобщенная регрессионная нейро-фаззи сеть, нечеткая машина опорных векторов, ядерная функция активации.

Deineko A. A., Pliss I. P., Bodyanskiy Ye.

EVOLVING NEURO-FUZZY SYSTEM COMBINED LEARNING

In this work the evolving neuro-fuzzy system with kernel activation function that contains fuzzy support vector machine, normalized radial basis function neural network and general regression neuro-fuzzy network as subsystems is proposed. This network is tuned using both optimization and memory based approaches and does not inclined to the "curse of dimensionality», is able to real time mode information processing by adapting its parameters and structure to problem conditions.

Key words: evolving neuro-fuzzy system, normalized radialbasis function neural network, general regression neuro-fuzzy network, fuzzy support vector machine, kernel activation function.

\title{
OPTIMAL STRATEGIES CONTINUUM FOR PROJECTING THE FOUR- MOUNT CONSTRUCTION UNDER INTERVAL UNCERTAINTIES WITH INCORRECTLY PRE-EVALUATED TWO LEFT AND ONE RIGHT ENDPOINTS
}

\begin{abstract}
There is investigated a two-person game model of optimizing cross-section squares of the four-mount construction, where the model kernel is defined on the six-dimensional hyperparallelepiped as the product of three closed intervals of unit-normed loads and of three closed intervals of unit-normed cross-section squares. For the case of incorrectly pre-evaluated two left and one right endpoints of those interval uncertainties there has been proved that the projector may obtain an optimal strategies continuum. A criterion for singularizing that continuum has been proposed.
\end{abstract}

Key words: optimizing cross-section squares, two-person game model, four-mount construction, incorrect pre-evaluation.

\section{INVESTIGATIONAREA}

There are many uncertain factors in building mount constructions, one of which is interval-valued potential load on the construction pivots, pillars, bars or other mount elements $[1,2]$. If the potential load on the construction with four mounts is unit-normed, then the unit-normed load on the $i$-th mount $x_{i}$ is enclosed within the closed interval $\left[a_{i} ; b_{i}\right] \subset(0 ; 1)$ by $b_{i}>a_{i}$ for $i=\overline{1,3}[3,4]$. The nonzero 
fourth unit-normed load is

$$
x_{4}=1-x_{1}-x_{2}-x_{3}
$$

due to the unit-normalization. The problem is to take some mounting square against that potential load, and this square may be unit-normed also. Thus the $i$-th mount cross-section square is $y_{i}$, and due to analogous unit-normalization $y_{i} \in\left[a_{i} ; b_{i}\right] \subset(0 ; 1)$ for $i=\overline{1,3}$ by

$$
y_{4}=1-y_{1}-y_{2}-y_{3} \text {. }
$$

Obviously, that taking the unit-normed values shouldn't be arbitrary, but be optimal in the sense of minimizing the potential load and mounting square relationship $[3,5,6]$.

\section{AVAILABLE REFERENCES ANALYSIS}

There is a known model of optimizing the values $\left\{y_{i}\right\}_{i=1}^{3}$, stated as a convex game with the kernel [3, 7]

$$
\begin{gathered}
T(\mathbf{X}, \mathbf{Y})=T\left(x_{1}, x_{2}, x_{3} ; y_{1}, y_{2}, y_{3}\right)= \\
=\max \left\{x_{1} y_{1}^{-2}, x_{2} y_{2}^{-2}, x_{3} y_{3}^{-2}, \frac{1-x_{1}-x_{2}-x_{3}}{\left(1-y_{1}-y_{2}-y_{3}\right)^{2}}\right\}
\end{gathered}
$$

on the hyperparallelepiped

$$
\begin{aligned}
& \boldsymbol{X} \times \boldsymbol{Y}=\prod_{p=1}^{2}\left[a_{1} ; b_{1}\right] \times\left[a_{2} ; b_{2}\right] \times\left[a_{3} ; b_{3}\right]= \\
& =\prod_{p=1}^{2}\left(\prod_{i=1}^{3}\left[a_{i} ; b_{i}\right]\right) \subset \prod_{d=1}^{6}(0 ; 1) \subset \prod_{d=1}^{6}[0 ; 1] \subset \mathbb{R}^{6}
\end{aligned}
$$

of pure strategies

$$
\begin{aligned}
& \mathbf{X}=\left[\begin{array}{lll}
x_{1} & x_{2} & x_{3}
\end{array}\right] \in \\
& \in \boldsymbol{X}=\left[a_{1} ; b_{1}\right] \times\left[a_{2} ; b_{2}\right] \times\left[a_{3} ; b_{3}\right]= \\
& =\prod_{i=1}^{3}\left[a_{i} ; b_{i}\right] \subset \prod_{i=1}^{3}(0 ; 1) \subset \prod_{i=1}^{3}[0 ; 1] \subset \mathbb{R}^{3}
\end{aligned}
$$

of the first player and of pure strategies

$$
\begin{aligned}
& \mathbf{Y}=\left[\begin{array}{lll}
y_{1} & y_{2} & y_{3}
\end{array}\right] \in \\
& \in \boldsymbol{Y}=\left[a_{1} ; b_{1}\right] \times\left[a_{2} ; b_{2}\right] \times\left[a_{3} ; b_{3}\right]= \\
& =\prod_{i=1}^{3}\left[a_{i} ; b_{i}\right] \subset \prod_{i=1}^{3}(0 ; 1) \subset \prod_{i=1}^{3}[0 ; 1] \subset \mathbb{R}^{3}
\end{aligned}
$$

of the second. The first player personifies the natural factors, which can't be foreseen, and the second player personifies the projector or the person responsible for projecting the four-mount construction, being investigated. The optimal strategy

$$
\mathbf{Y}_{*}=\left[\begin{array}{ccc}
y_{1}^{*} & y_{2}^{*} & y_{3}^{*}
\end{array}\right] \in\left[a_{1} ; b_{1}\right] \times\left[a_{2} ; b_{2}\right] \times\left[a_{3} ; b_{3}\right]=\boldsymbol{Y}(7)
$$

of the projector, existing by the theorem on the second player optimal strategies in the convex game $[3,8]$, is determined from the four-parted equality

$$
\frac{b_{i}}{\left(y_{i}^{*}\right)^{2}}=\frac{1-a_{1}-a_{2}-a_{3}}{\left(1-y_{1}^{*}-y_{2}^{*}-y_{3}^{*}\right)^{2}} \text { by } i=\overline{1,3} \text {. }
$$

However, the given bounded intervals $\left\{\left[a_{i} ; b_{i}\right]\right\}_{i=1}^{3}$ uncertainties may occur such that the equality (8) is not true [9] within the parallelepiped (6). Then it is spoken about incorrectness of left or right endpoints of those intervals. If these endpoints were corrected (increased or decreased, as needed) then the equality (8) would have been turned true within the parallelepiped (6). But this is impossible, so preevaluations $\left\{a_{i}\right\}_{i=1}^{3}$ and $\left\{b_{i}\right\}_{i=1}^{3}$ are held still.

\section{WORKGOAL}

Will find the projector optimal strategy (7) in supposition that here are interval uncertainties $\left\{\left[a_{i} ; b_{i}\right]\right\}_{i=1}^{3}$ with incorrectly pre-evaluated two left and one right endpoints. If they all were correct the components of the projector optimal strategy (7) would have been [7]

$$
y_{i}^{*}=\frac{\sqrt{b_{i}}}{\sqrt{b_{1}}+\sqrt{b_{2}}+\sqrt{b_{3}}+\sqrt{1-a_{1}-a_{2}-a_{3}}} \quad \forall i=\overline{1,3} .
$$

But the endpoints $a_{p}, a_{q}$ and $b_{k}$ by $\{p, q, k\}=\{1,2,3\}$ have occurred such that

$$
\begin{gathered}
\frac{\sqrt{b_{p}}}{\sqrt{b_{1}}+\sqrt{b_{2}}+\sqrt{b_{3}}+\sqrt{1-a_{1}-a_{2}-a_{3}}}<a_{p}, \\
\frac{\sqrt{b_{q}}}{\sqrt{b_{1}}+\sqrt{b_{2}}+\sqrt{b_{3}}+\sqrt{1-a_{1}-a_{2}-a_{3}}}<a_{q},
\end{gathered}
$$

$$
\frac{\sqrt{b_{k}}}{\sqrt{b_{1}}+\sqrt{b_{2}}+\sqrt{b_{3}}+\sqrt{1-a_{1}-a_{2}-a_{3}}}>b_{k} .
$$

It means that

$$
y_{p}^{*}>\frac{\sqrt{b_{p}}}{\sqrt{b_{1}}+\sqrt{b_{2}}+\sqrt{b_{3}}+\sqrt{1-a_{1}-a_{2}-a_{3}}},
$$




$$
\begin{aligned}
& y_{q}^{*}>\frac{\sqrt{b_{q}}}{\sqrt{b_{1}}+\sqrt{b_{2}}+\sqrt{b_{3}}+\sqrt{1-a_{1}-a_{2}-a_{3}}}, \\
& y_{k}^{*}<\frac{\sqrt{b_{k}}}{\sqrt{b_{1}}+\sqrt{b_{2}}+\sqrt{b_{3}}+\sqrt{1-a_{1}-a_{2}-a_{3}}},
\end{aligned}
$$

and for finding the projector optimal strategy (7) there has to be used the impossibility of the equality (8) within the parallelepiped (6) up with the conditions (10)-(12). Clearly that the conditions (10)-(12), meaning (13)-(15), also give one of the four following inequalities, which breaks the equality (8):

$$
\begin{gathered}
\frac{1}{b_{k}}>\frac{b_{r}}{a_{r}^{2}}>\frac{1-a_{1}-a_{2}-a_{3}}{\left(1-a_{p}-a_{q}-b_{k}\right)^{2}} \text { by } r \in\{p, q\}, \\
\frac{1}{b_{k}}>\frac{b_{p}}{a_{p}^{2}} \geqslant \frac{1-a_{1}-a_{2}-a_{3}}{\left(1-a_{p}-a_{q}-b_{k}\right)^{2}} \geqslant \frac{b_{q}}{a_{q}^{2}}, \\
\frac{1}{b_{k}} \geqslant \frac{1-a_{1}-a_{2}-a_{3}}{\left(1-a_{p}-a_{q}-b_{k}\right)^{2}}>\frac{b_{r}}{a_{r}^{2}} \text { by } r \in\{p, q\}, \\
\frac{1-a_{1}-a_{2}-a_{3}}{\left(1-a_{p}-a_{q}-b_{k}\right)^{2}}>\frac{1}{b_{k}}>\frac{b_{r}}{a_{r}^{2}} \text { by } r \in\{p, q\} .
\end{gathered}
$$

The inequalities (16)-(18) are united into the single inequality

$$
\frac{1}{b_{k}} \geqslant \frac{1-a_{1}-a_{2}-a_{3}}{\left(1-a_{p}-a_{q}-b_{k}\right)^{2}}
$$

that is going to be the last pre-condition for finding the projector optimal strategy (7).

\section{THEOREMONCONTINUUM OF PROJECTOR} OPTIMALSTRATEGIES (7) UNDER (10)-(12) BY (20)

Theorem. In the game with kernel (3) on the hyperparallelepiped (4) by the conditions (10)-(12) and (20) the components of the projector optimal strategy (7) are

$$
y_{r}^{*} \in\left[a_{r} ; b_{r}\right] \text { by } r \in\{p, q\}
$$

at

$$
b_{p}+b_{q} \leqslant 1-b_{k}-\sqrt{b_{k}\left(1-a_{1}-a_{2}-a_{3}\right)}
$$

or

$$
y_{r}^{*} \in\left[a_{r} ; y_{r}^{\langle\max \rangle}\right] \text { by } r \in\{p, q\}
$$

$$
b_{p}+b_{q}>1-b_{k}-\sqrt{b_{k}\left(1-a_{1}-a_{2}-a_{3}\right)}
$$

for

$$
y_{p}^{\langle\max \rangle}+y_{q}^{\langle\max \rangle}=1-b_{k}-\sqrt{b_{k}\left(1-a_{1}-a_{2}-a_{3}\right)},
$$

where

$$
y_{k}^{*}=b_{k} \text {. }
$$

In the case of the inequality

$$
\frac{1}{b_{k}}>\frac{1-a_{1}-a_{2}-a_{3}}{\left(1-a_{p}-a_{q}-b_{k}\right)^{2}}
$$

the projector has a continuum of its optimal strategies (7).

Proof. As the inequality (20), being the corollary of the conditions (10)-(15), is true then the second player cannot make its payoffless than $\frac{1}{b_{k}}$. This payoff value is the optimal game value $v_{*}=\frac{1}{b_{k}}$, which is reached at the right endpoint of the $k$-th rib of the parallelepiped (6). If $y_{k}<b_{k}$ then the payoff is greater than $v_{*}$, what is unacceptable for the projector, so (26) is the single possible $k$-th component of the projector optimal strategy (7). Going further, the inequality (20) may be overstated as

$$
\left(1-a_{p}-a_{q}-b_{k}\right)^{2} \geqslant b_{k}\left(1-a_{1}-a_{2}-a_{3}\right)
$$

or

$$
1-a_{p}-a_{q}-b_{k} \geqslant \sqrt{b_{k}\left(1-a_{1}-a_{2}-a_{3}\right)},
$$

where it has been root-extracted due to positiveness of the fourth unit-normed cross-section square. So, the projector should select such $y_{p}^{*}$ and $y_{q}^{*}$ that the inequality

$$
1-y_{p}^{*}-y_{q}^{*}-b_{k} \geqslant \sqrt{b_{k}\left(1-a_{1}-a_{2}-a_{3}\right)}
$$

would turn true. The inequality (30) is overstated as the condition

$$
y_{p}^{*}+y_{q}^{*} \leqslant 1-b_{k}-\sqrt{b_{k}\left(1-a_{1}-a_{2}-a_{3}\right)}
$$

for selecting the components $y_{p}^{*}$ and $y_{q}^{*}$. Then if(22) is true then (31) is true $\forall y_{r}^{*} \in\left[a_{r} ; b_{r}\right]$ by $r \in\{p, q\}$ and therefore the $r$-th component of the projector optimal strategy (7) is (21). Otherwise, if(24) is true then (31) is true for such $y_{p}^{*}$ and $y_{q}^{*}$ that their sum is not greater than the right side of (31). So, the $r$-th component is selected as (23) for (25). The 
continuum of projector optimal strategies with the inequality (27) is subsequent to that $y_{r}^{*}>a_{r}$ at $r \in\{p, q\}$ for the case with (22) and either $y_{p}^{\langle\max \rangle}>a_{p}$ or $y_{q}^{\langle\max \rangle}>a_{q}$ for the case with (24). The theorem has been proved.

It remains only to constate that in the case of the equality

$$
\frac{1}{b_{k}}=\frac{1-a_{1}-a_{2}-a_{3}}{\left(1-a_{p}-a_{q}-b_{k}\right)^{2}}
$$

the projector does not have more than the single optimal strategy (7) as here its components are $y_{r}^{*}=a_{r}$ by $r \in\{p, q\}$ and, undoubtedly, (26). Let

Consider an example of applying the proved theorem.

$$
\begin{gathered}
a_{1}=0,24, b_{1}=0,26, a_{2}=0,26, \\
b_{2}=0,29, a_{3}=0,1, b_{3}=0,2 .
\end{gathered}
$$

Having calculated the values (9), here (10)-(12) are true:

$$
\begin{gathered}
\frac{\sqrt{b_{1}}}{\sqrt{b_{1}}+\sqrt{b_{2}}+\sqrt{b_{3}}+\sqrt{1-a_{1}-a_{2}-a_{3}}}< \\
<0,23961<a_{1}=0,24, \\
\frac{\sqrt{b_{2}}}{\sqrt{b_{1}}+\sqrt{b_{2}}+\sqrt{b_{3}}+\sqrt{1-a_{1}-a_{2}-a_{3}}}< \\
<0,2531<a_{2}=0,26, \\
\frac{\sqrt{b_{3}}}{\sqrt{b_{1}}+\sqrt{b_{2}}+\sqrt{b_{3}}+\sqrt{1-a_{1}-a_{2}-a_{3}}}> \\
>0,2101>b_{3}=0,2 .
\end{gathered}
$$

Also the inequality (17) is true, that is (20) is the precondition for finding the projector optimal strategy (7). So, as

$$
\begin{gathered}
b_{1}+b_{2}=0,55>0,5172> \\
>1-b_{3}-\sqrt{b_{3}\left(1-a_{1}-a_{2}-a_{3}\right)}
\end{gathered}
$$

is true, that is the condition (24) is true, then here the projector optimal strategy (7) components are (23) for (25) and (26):

$$
\begin{gathered}
y_{1}^{*} \in\left[0,24 ; y_{1}^{\langle\max \rangle}\right], \\
y_{2}^{*} \in\left[0,26 ; y_{2}^{\langle\max \rangle}\right], y_{3}^{*}=0,2,
\end{gathered}
$$

where

$$
y_{1}^{\langle\max \rangle}+y_{2}^{\langle\max \rangle}=0,8-0,2 \sqrt{2} \text {. }
$$

\section{CONCLUSIONAND WORKING FURTHER PERSPECTIVE}

The disclosed continuum of the projector optimal strategy (7) under strictness in the inequality sign must not delude an explorer or a real constructor, because the summed unit-normed cross-section squares are fixed at unit, and it may select $y_{p}^{*}$ and $y_{q}^{*}$ whatever, just satisfying (21) or (23) with (25). Nevertheless, this selection could have been rational due to some criterion with respect to $y_{p}^{*}, y_{q}^{*}$, $y_{4}^{*}=1-y_{p}^{*}-y_{q}^{*}-b_{k}$. One of suchlike criterions is equalization of values $y_{p}^{*}, y_{q}^{*}, y_{4}^{*}$, that is solving the problem

$$
\min _{\left[a_{p} ; b_{p}\right] \times\left[a_{q} ; b_{q}\right]}\left(\max \left\{\frac{y_{p}^{*}}{y_{q}^{*}}, \frac{y_{q}^{*}}{y_{p}^{*}}, \frac{y_{p}^{*}}{y_{4}^{*}}, \frac{y_{4}^{*}}{y_{p}^{*}}, \frac{y_{q}^{*}}{y_{4}^{*}}, \frac{y_{4}^{*}}{y_{q}^{*}}\right\}\right)
$$

or

$$
\min _{\left[a_{p} ; y_{p}^{\langle\max \rangle}\right] \times\left[a_{q} ; y_{q}^{\langle\max \rangle}\right]}\left(\max \left\{\frac{y_{p}^{*}}{y_{q}^{*}}, \frac{y_{q}^{*}}{y_{p}^{*}}, \frac{y_{p}^{*}}{y_{4}^{*}}, \frac{y_{4}^{*}}{y_{p}^{*}}, \frac{y_{q}^{*}}{y_{4}^{*}}, \frac{y_{4}^{*}}{y_{q}^{*}}\right\}\right) .
$$

In perspective, there should be worked the situation with the inequality (19), which seems to be more complicated in finding the projector optimal strategy (7).

\section{REFERENCES}

1. Дарков, А. В. Строительная механика : [учебник для строит. спец. вузов] / А. В. Дарков, Н. Н. Шапошников. - [8-е изд., перераб. и доп.]. - М. : Высш. шк., 1986. - 607 с.

2. Киселев, В. А. Строительная механика: Спец. курс. Динамика и устойчивость сооружений : [учебник для вузов] / В. А. Киселев. - [3-е изд., испр. и доп.]. - М. : Стройиздат, 1980. $-616 \mathrm{c}$.

3. Воробьев, Н. Н. Теория игр для экономистов-кибернетиков / Н. Н. Воробьев. - М. : Наука, Главная редакция физико-математической литературы, 1985. - 272 с.

4. Романюк, В. В. Моделювання дії нормованого одиничного навантаження на три колони однакової висоти у будівельній конструкції і знаходження оптимальної площі кожної опори / В. В. Романюк // Проблеми трибології. 2010. - № 3. - С. 18-25.

5. Трухаев, Р. И. Модели принятия решений в условиях неопределенности / Р. И. Трухаев. - М. : Наука, 1981. - 258 с.

6. Черноруцкий, И. Г. Методы принятия решений / И. Г. Черноруцкий - С. Пб. : БХВ-Петербург, 2005. - 416 с.

7. Романюк, В. В. Регулярна оптимальна стратегія проектувальника у моделі дії нормованого одиничного навантаження на $N$-колонну будівельну конструкцію-опору / В. В. Романюк // Проблеми трибологіï. - 2011. - № 2. - С. 111-114.

8. Теория игр : [учеб. пособие для ун-тов] / Л. А. Петросян, Н. А. Зенкевич, Е. А. Семина. - М. : Высшая школа, Книжный дом «Университет», 1998. - 304 с. 
9. Романюк, В. В. Про особливі компоненти оптимальної стратегії проектувальника у моделі дії нормованого одиничного навантаження на триколонну будівельну конструкцію / В. В. Романюк // Проблеми трибології. - 2011. № 1. - C. 44-46.

Романюк В. В.

Стаття надійшла до редакції 04.10.2011.

КОНТИНУУМ ОПТИМАЛЬНЫХ СТРАТЕГИЙ ДЛЯ ПРОЕКТИРОВАНИЯ ЧЕТЫРЕХОПОРНОЙ КОНСТРУКЦИИ В УСЛОВИЯХ ИНТЕРВАЛЬНЫХ НЕОПРЕДЕЛЕННОСТЕЙ С ПРЕДВАРИТЕЛЬНО НЕКОРРЕКТНО ОЦЕНЕННЫМИ ДВУМЯ ЛЕВЫМИ И ОДНИМ ПРАВЫМ КОНЦАМИ

Исследуется игровая модель двух лиц в оптимизации площадей поперечного сечения четырехопорной конструкции, где модельное ядро определяется на шестимерном гиперпараллелепипеде как произведении трех замкнутых интервалов единично нормированных нагрузок и трех замкнутых интервалов единично нормированных площадей поперечного сечения. Для случая предварительно некорректно оцененных двух левых и одного правого концов этих интервальных неопределенностей доказано, что проектировщик может получать континуум оптимальных стратегий. Предложен критерий для выделения единственного элемента из этого континуума.
Ключевые слова: оптимизация площадей поперечного сечения, игровая модель двух лиц, четырехопорная конструкция, некорректное предварительное оценивание.

Романюк В. В

КОНТИНУУМ ОПТИМАЛЬНИХ СТРАТЕГІЙ ДЛЯ ПРОЕКТУВАННЯ ЧОТИРЬОХОПОРНОЇ КОНСТРУКЦІЇ В УМОВАХ ІНТЕРВАЛЬНИХ НЕВИЗНАЧЕНОСТЕЙ 3 ПОПЕРЕДНЬО НЕКОРЕКТНО ОЦІНЕНИМИ ДВОМА ЛІВИМИ Й ОДНИМ ПРАВИМ КІНЦЯМИ

Досліджується ігрова модель двох осіб в оптимізації площ поперечного перерізу чотирьохопорної конструкції, де модельне ядро задається на шестивимірному гіперпаралелепіпеді як добутку трьох замкнених інтервалів одинично нормованих навантажень і трьох замкнених інтервалів одинично нормованих площ поперечного перерізу. Для випадку попередньо некоректно оцінених двох лівих й одного правого кінців цих інтервальних невизначеностей доведено, що проектувальник може отримувати континуум оптимальних стратегій. Запропоновано критерій для виокремлення єдиного елемента 3 цього континуума.

Ключові слова: оптимізація площ поперечного перерізу, ігрова модель двох осіб, чотирьохопорна конструкція, некоректне попереднє оцінювання.

\title{
КОНСТРУИРУЕМЫЕ ПРИЗНАКИ ДЛЯ АВТОМАТИЧЕСКОЙ КЛАССИФИКАЦИИ РАСПРЕДЕЛЕННЫХ ВО ВРЕМЕНИ СТАЦИОНАРНЫХ СИГНАЛОВ
}

\begin{abstract}
Решена актуальная задача автоматизации сокращения размерности данных для построения диагностических и распознающих моделей на основе стационарных одномерных сигналов, распределенных во времени. Впервые предложен комплекс показателей, характеризующих свойства сигналов, позволяющий существенно сократить описание классифицируемых объектов. Проведены эксперименты по исследованию предложенного комплекса показателей при решении практических задач.
\end{abstract}

Ключевые слова: распознавание образов, техническое диагностирование, признак, стационарный сигнал, извлечение признаков.

\section{ВВЕДЕНИЕ}

Одной из проблем, возникающих при построении распознающих и диагностических моделей стационарных объектов на основе сигналов, распределенных во времени, является низкая индивидуальная информативность признаков, которая при ограниченном объеме выборки отягощается большим числом признаков. В результате получаемая распознающая модель, как правило, оказывается громоздкой и сложной (как следствие этого, также характеризуется низким уровнем обобщения обучающих данных), а также крайне неудобной для последующего анализа и интерпретации человеком. Процесс построения распознающей модели по выборкам, характеризующимся большим числом признаков, также требует значительных затрат ресурсов памяти ЭВМ (как оперативной, так и дисковой) для хранения и обработки обучающих данных.

Поэтому актуальной является задача сокращения описания стационарных сигналов, распределенных во времени с целью получения интерпретабельных распознающих и диагностических моделей, обеспечивающих высокий уровень обобщения относительно обучающей выборки данных.

\section{1. ПОСТАНОВКА ЗАДАЧИ СОКРАЩЕНИЯ ОПИСАНИЯСИГНАЛОВ}

Пусть задана исходная выборка наблюдений $\langle x, y>$, где $x=\left\{x^{s}\right\}, x=\left\{x_{j}\right\}, x^{s}=\left\{x_{j}^{s}\right\}, x_{j}=\left\{x_{j}^{s}\right\}, y=\left\{y^{s}\right\}, s=1,2, \ldots, S, j=1,2, \ldots$, $N, x_{j}^{s}$-значение $j$-го диагностического признака $x_{j}$, характе- 